\title{
POTENSI EKSTRAK OLIGOSAKARIDA UBI JALAR SEBAGAI PREBIOTIK BAKTERI PROBIOTIK AKUAKULTUR \\ (The Potential of Sweet Potato Oligosaccharide Extract as Aquaculture Probiotic Bacteria Prebiotic)
}

\author{
Wida Lesmanawati ${ }^{1}$, Widanarni $^{2}$, Sukenda $^{2}$, Wahyu Purbiantoro ${ }^{3}$ \\ ${ }^{1}$ Program Diploma, Institut Pertanian Bogor.wida.lesmana@yahoo.com \\ ${ }^{2}$ Departemen Budidaya Perairan, Institut Pertanian Bogor. \\ ${ }^{3}$ UPT Balai Konservasi Biota Laut Ambon, Puslit Oseanografi - LIPI
}

Diterima 2 Juli 2013/ Disetujui 17 Juli 2013

\begin{abstract}
Sweet potato contains non digestible oligosaccharides that functions as prebiotics. The processing will affect the chemical composition of sweet potato. This study aimed to find the best preparation method of sweet potato (Ipomoea batatas) that can produce the highest oligosaccharide extract and test the prebiotic potential of the extract to support the growth of bacteria SKT-b which has been shown to act as a probiotic for shrimp. Trial I: test the preparation method of sweet potato to obtain the best oligosaccharides extract. The treatment consisted of three different preparation methods, raw potato flour, raw potato flour steamed, and steamed potato flour. Oligosaccharides from potato flour of each preparation method was then extracted and analyzed using High Performance Liquid Chromatography. Potato oligosaccharides extract from best preparation method, was dried in freeze dryer and used for later experiments. Trial II: test the potato oligosaccharides extract as prebiotic in supporting the growth of probiotic bacteria SKT-b (in vitro). This experiment was conducted to determine the combinations of prebiotic dose with inoculants concentrations that result the best growth of bacteria SKT-b. Liquid culture bacteria SKT-b concentrations of $10^{7}, 10^{8}$, $10^{9}$, and $10^{10}$ cfu $\mathrm{ml}^{1}$ were cultured in sterile sea water mixed with prebiotics concentrations of $0,1,2$ and $3 \% \mathrm{v} / \mathrm{v}$. The extract of steamed potato flour contains the highest oligosaccharides, and may act as prebiotics to support the growth of probiotic bacteria SKT-b. Prebiotics 3\% and probiotics SKT-b $10^{10} \mathrm{cfu} \mathrm{ml}^{1}$ was the best sinbiotic combination, which showed the highest growth of probiotic bacteria.
\end{abstract}

Keywords: oligosaccharides, probiotics SKT-b, sinbiotic, sweet potato

\section{PENDAHULUAN}

Konsep prebiotik pertama kali diperkenalkan Gibson dan Roberfroid (1995) sebagai bahan makanan tidak dicerna (non-digestible food ingredient) yang memberikan efek menguntungkan pada inang sebab secara selektif merangsang pertumbuhan bakteri dalam kolon sehingga dapat meningkatkan kesehatan inang. Oleh penulis yang sama konsep tersebut direvisi dan kemudian diajukan definisi prebiotik baru yaitu bahan yang difermentasi secara selektif sehingga menyebabkan perubahan spesifik baik pada komposisi dan atau aktivitas mikrobiota dalam kolon yang memberikan manfaat kesehatan pada inang (Gibson et al. 2004; Roberfroid 2007). Prebiotik umumnya merupakan karbohidrat (poli- dan oligosakarida) yang tidak dapat dicerna dalam saluran pencernaan inang. Kandungan karbohidrat tinggi dapat ditemukan dalam ubi-ubian, salah satunya adalah ubi jalar. Data tahun 2009 menunjukkan produksi ubi jalar Indonesia menempati urutan keempat setelah China, Uganda dan Nigeria (Wikipedia 2012). Melimpahnya produksi mengakibatkan harganya relatif murah sehingga potensial digunakan sebagai bahan baku untuk diolah menjadi produk yang memiliki nilai tambah lebih. Beberapa penelitian menemukan bahwa ubi jalar mengandung oligosakarida tidak dicerna (non-digestible oligosaccharides [NDOs]) diantaranya rafinosa dan sukrosa yang berfungsi sebagai prebiotik (Marlis 2008; Putra 2010; Haryati dan Supriyati 2010). Komposisi kimia ubi jalar bervariasi tergantung pada waktu panen, varietas dan proses pengolahan. Pengukusan dapat meningkatkan konsentrasi gula dalam ubi jalar dibandingkan dengan kondisi mentahnya (Marlis 2008).

Penggunaan probiotik bagi kegiatan akuakultur telah menarik banyak perhatian baik untuk tujuan penelitian maupun komersial (Nayak 2010). Salah satunya adalah bakteri SKT-b yang berhasil diisolasi dari Skeletonema, secara in vitro maupun in vivo, terbukti mampu berperan sebagai probiotik (Widanarni et al. 2003). Bakteri SKT-b mampu menekan populasi bakteri Vibrio harveyi, meningkatkan sintasan larva udang windu yang terinfeksi vibriosis, dan mampu menstimulasi sistem imunitas udang vaname (Widanarni et al. 2003; Widanarni et al. 2008; Syahailatua 2009). Berbagai penelitian telah menunjukkan keuntungan aplikasi probiotik dan prebiotik pada hewan akuatik (Merrifield et al. 2010; Nayak 2010; Ringo et al. 2010). Aplikasi penggunaan probiotik dan prebiotik ini pada umumnya diteliti secara terpisah, sebaliknya sinbiotik belum banyak dipelajari. Sinbiotik merupakan aplikasi kombinasi dari probiotik dan prebiotik, didasarkan pada prinsip menyediakan probion yang kompetitif (mampu memfermentasi sumber energi) selama bersaing dengan populasi endogen, sehingga secara efektif meningkatkan kelangsungan hidup dan perlekatan dari mikrobial hidup yang diberikan, pada saluran pencernaan inang(Gibson and Roberfroid 1995). Berdasarkan beberapa penelitian, pemberian 
sinbiotik pada hewan akuatik menunjukkan hasil yang lebih baik dibandingkan bila diaplikasikan secara terpisah (Li et al. 2009; Rodriguez-Estrada et al. 2009; Zhang et al. 2010). Penelitian ini bertujuan untuk mencari metode preparasi ubi jalar terbaik yang dapat menghasilkan ekstrak oligosakarida paling tinggi serta menguji potensi prebiotik dari ekstrak tersebut dalam menunjang pertumbuhan bakteri probiotik SKT-b secara in vitro.

\section{METODOLOGI}

\section{Percobaan Tahap I: Pengujian Metode Preparasi Ubi Jalar untuk Memperoleh Ekstrak Oligosakarida} Terbaik.

Percobaan tahap satu dilakukan untuk mengetahui metode preparasi yang menghasilkan konsentrasi ekstrak oligosakarida paling tinggi. Perlakuan terdiri dari tiga metode preparasi berbeda (Tabel 1). Masingmasing tepung ubi jalar hasil preparasi tersebut selanjutnya diekstraksi dalam etanol $70 \%$ dengan perbandingan 1:10 dan digoyang (kecepatan $120 \mathrm{rpm}$ suhu $30^{\circ} \mathrm{C}$ ) selama 15 jam (Muchtadi 1989). Setelah disaring, filtrat yang diperoleh dipekatkan menggunakan vacum evaporator pada suhu $40^{\circ} \mathrm{C}$ sampai tidak ada alkohol yang menguap ( $\pm 1 / 3$ volume awal). Filtrat yang telah dipekatkan (ekstrak oligosakarida) selanjutnya dianalisis kandungan oligosakaridanya menggunakan high performance liquid chromatography (HPLC).

Tabel 1 Metode preparasi tepung ubi jalar sebagai bahan baku ekstrak oligosakarida

\begin{tabular}{lll}
\hline \multicolumn{1}{c}{ Metode 1 } & \multicolumn{1}{c}{ Metode 2 } & \multicolumn{1}{c}{ Metode 3 } \\
\hline $\begin{array}{l}\text { Ubi mentah diiris tipis, kemudian } \\
\text { dikeringkan dalam oven pada }\end{array}$ & $\begin{array}{l}\text { Tepung ubi mentah (metode 1) } \\
\text { dicampur dengan akuades 1:1, }\end{array}$ & Ubi jalar dipotong dua sampai \\
suhu $50^{\circ} \mathrm{C}$ selama dua hari dan & kemudian dikukus selama 30 & besarnya ubi jalar) kemudian \\
selanjutnya ditepungkan & menit, dikeringkan kembali dalam & dikukus selama 30 menit, \\
menggunakan blender (tepung & oven pada suhu $50^{\circ} \mathrm{C}$ dan & selanjutnya diiris tipis, dikeringkan \\
ubi mentah) & selanjutnya ditepungkan & dalam oven pada suhu 50 ${ }^{\circ} \mathrm{C}$ \\
& menggunakan blender (tepung & selama dua hari, dan ditepungkan \\
& ubi mentah kukus) & menggunakan blender (tepung \\
& & ubi kukus)
\end{tabular}

Metode preparasi ubi jalar yang menghasilkan ekstrak oligosakarida dengan kandungan oligosakarida terbaik, kemudian dikeringkan dengan freeze dryer untuk memisahkan filtrat dari pelarut yang tersisa. Ekstrak oligosakarida hasil freeze dryer selanjutnya dianalisis kembali kandungan oligosakaridanya menggunakan HPLC. Analisis oligosakarida dengan HPLC menggunakan kolom Aminex HPX-87H pada suhu $35^{\circ} \mathrm{C}$ dengan refractive indeks detector, laju alir $1 \mathrm{ml} \mathrm{menit}^{-1}$, fase gerak $\mathrm{H}_{2} \mathrm{SO}_{4} 0.008 \mathrm{~N}$ dan volume injeksi $20 \mu \mathrm{l}$.

\section{Percobaan Tahap II : Pengujian Prebiotik Ekstrak Oligosakarida Ubi Jalar dalam Menunjang Pertumbuhan Bakteri Probiotik SKT-b secara In Vitro.}

Sebelum uji in vitro dilakukan, terlebih dahulu dibuat kurva pertumbuhan untuk mengetahui waktu inkubasi bakteri SKT-b pada puncak pertumbuhannya. Pembuatan kurva pertumbuhan dimulai dengan mengkultur bakteri SKT-b pada media seawater complete (SWC) cair dan diinkubasi dalam waterbath shaker (kecepatan $140 \mathrm{rpm}$, suhu $29^{\circ} \mathrm{C}$ ) selama 22 jam. Selanjutnya, setiap dua jam kultur bakteri diambil sebanyak 1 $\mathrm{ml}$ untuk dihitung konsentrasinya dengan metode total plate count (TPC) pada media TCBS agar.

Prosedur uji in vitro untuk menentukan kombinasi dosis prebiotik dengan konsentrasi inokulan yang menghasilkan pertumbuhan bakteri SKT-b optimal dimulai dengan menumbuhkan biakan cair bakteri SKT-b pada konsentrasi $10^{7}, 10^{8}, 10^{9}$, dan $10^{10} \mathrm{cfu} \mathrm{ml}^{-1}$, masing-masing sebanyak $1 \mathrm{ml}$ dalam $9 \mathrm{ml}$ air laut steril yang telah dicampur dengan prebiotik konsentrasi $0,1,2$ dan 3\% v/v. Sterilisasi prebiotik dilakukan dengan filtrasi mess size $0.20 \mu \mathrm{m}$. Biakan bakteri selanjutnya diinkubasi dalam waterbath shaker (kecepatan $140 \mathrm{rpm}$, suhu 29 ${ }^{\circ} \mathrm{C}$ ) selama 12 jam. Waktu inkubasi yang digunakan lebih pendek dari waktu optimal yang diperoleh dari hasil analisa kurva pertumbuhan sehingga diharapkan dapat terlihat perbedaan pertumbuhan bakteri SKT-b dengan lebih baik antar perlakuannya. Pertumbuhan bakteri SKT-b diketahui dengan mengukur nilai absorbansi biakan setiap perlakuan menggunakan spektrofotometer pada panjang gelombang $600 \mathrm{~nm}$.

\section{HASIL DAN PEMBAHASAN}

\section{Percobaan Tahap I}

Perubahan kandungan karbohidrat pada ubi jalar dapat terjadi selama proses pemeraman, penyimpanan dan pemrosesan (Van Den et al. 1986). Hasil penelitian ini menunjukkan proses pengukusan dapat meningkatkan kadar oligosakarida yang diindikasikan dengan meningkatnya kandungan oligosakarida hasil ekstraksi tepung ubi metah kukus (metode 2) dan tepung ubi kukus (metode 3) dibandingkan dengan 
tepung ubi mentah (metode 1). Konsentrasi rafinosa dan sukrosa tertinggi diperoleh dari hasil ekstraksi tepung ubi kukus sebesar 2.62\% dan 17.09\%, dengan total kandungan oligosakarida mencapai 19.71\% (Gambar 1). Meningkatnya konsentrasi rafinosa, sukrosa dan total oligosakarida dari ubi jalar setelah mengalami proses pengukusan disebabkan terjadinya proses hidrolisis pati menjadi oligosakarida dan kemudian monosakarida akibat pemanasan (Jood et al. 1988; Marlis 2008).

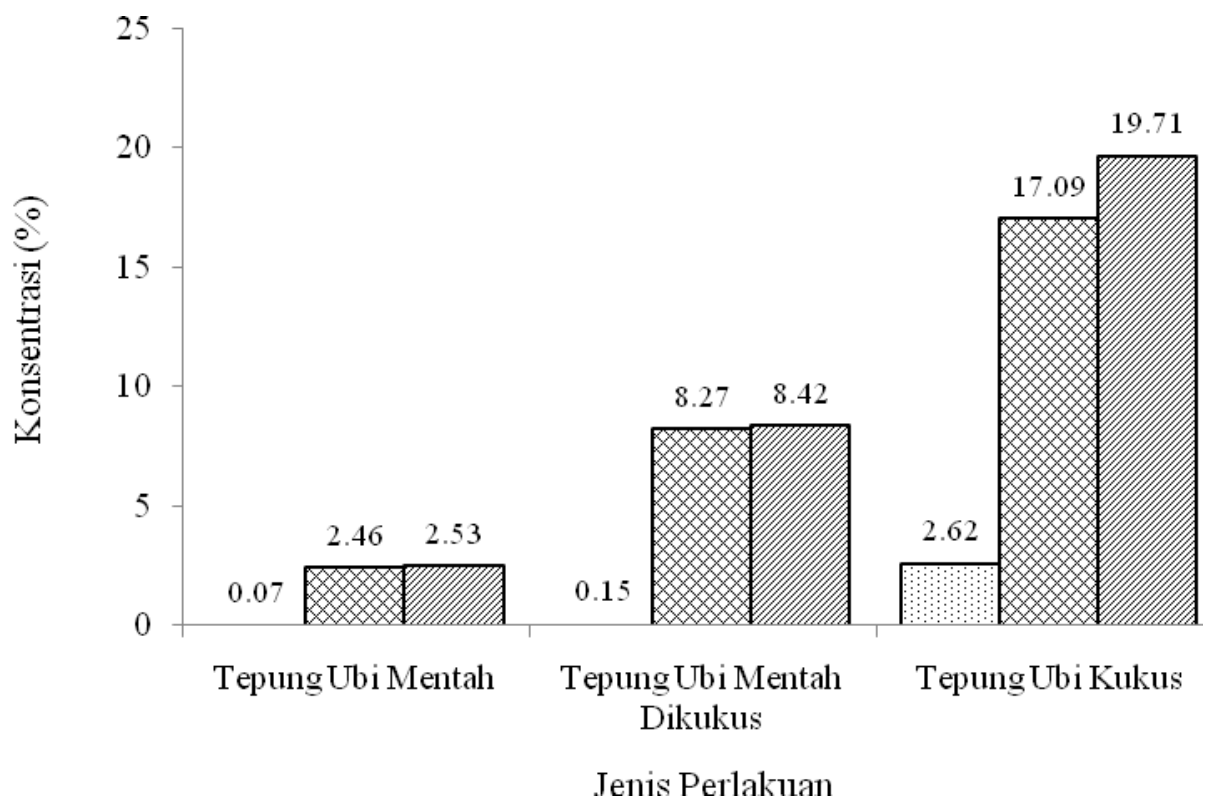

Gambar 1 Konsentrasi oligosakarida yang terkandung dalam ekstrak tepung ubi jalar sebelum di freeze dryer pada berbagai perlakuan metode preparasi. Rafinosa $\square$, sukrosa ( $\square$ dan total oligosakarida $(\square$

Hasil ekstraksi ubi jalar menunjukkan metode 3 (tepung ubi kukus) merupakan metode pemrosesan ubi jalar yang menghasilkan konsentrasi total oligosakarida tertinggi. Lebih lanjut, pengeringan ekstrak tepung ubi kukus menggunakan freeze dryer dapat meningkatkan konsentrasi oligosakarida karena lepasnya pelarut dari ekstrak. Konsentrasi total oligosakarida dalam ekstrak tepung ubi kukussetelah pengeringan meningkat dari $19.71 \%$ menjadi $64.86 \%$ (Gambar 2). Hasil analisis HPLC juga mendeteksi jenis oligosakarida lain selain rafinosa dan sukrosa yaitu maltoheptaosa, yang tidak terdeteksi pada ekstrak ubi jalar sebelum proses pengeringan dikarenakan konsentrasinya yang terlalu kecil. Sukrosa merupakan jenis oligosakarida dengan persentase konsentrasi tertinggi (52.86\%) diikuti rafinosa dan maltoheptaosa masing-masing $8.14 \%$ dan $3.86 \%$. Terbentuknya maltosa akibat pecahnya stuktur pati dilaporkan juga oleh Picha (1985) serta Bradbury dan Holloway (1988) pada ubi jalar yang direbus, dikukus dan dipanggang.

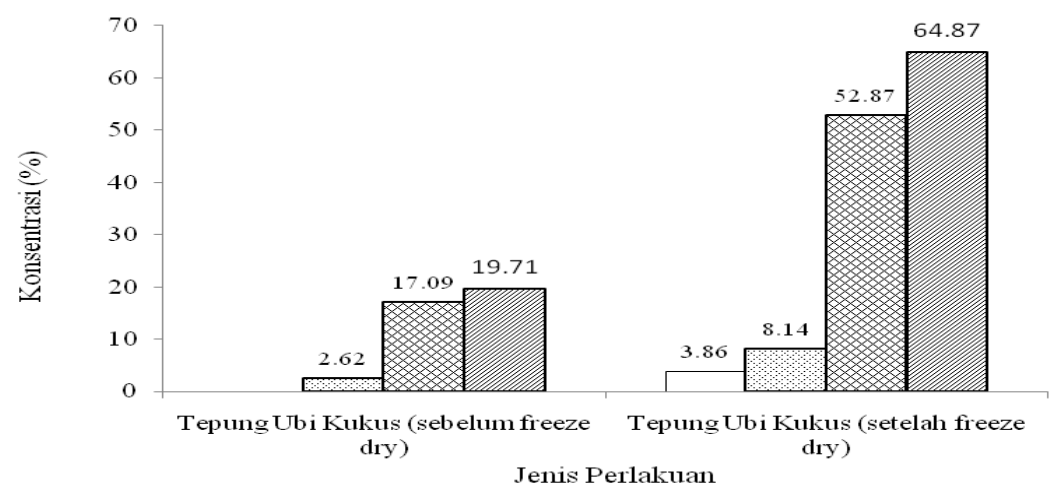

Gambar 2 Konsentrasi oligosakarida yang terkandung dalam ekstrak tepung ubi jalar kukus sebelum dan setelah di freeze dry. Maltoheptaosa ( $\square$ rafinosa ( $\square$, sukrosa ( $\square$ dan total oligosakarida ( $) \square$ 


\section{Percobaan Tahap II}

Bakteri SKT-b yang digunakan memiliki ciri koloni berbentuk bulat, elevasi cembung, tepian rata, berwarna kuning pada media Thiosulfate Citrate Bilesalt Sucrose(TCBS) agar dan agak berlendir. Pengamatan fase pertumbuhan biakan bakteri SKT-b yang dikultur pada media SWC menunjukkan puncak pertumbuhan bakteri terjadi pada jam ke 16 dengan konsentrasi bakteri mencapai $5.9 \times 10^{10} \mathrm{cfu} \mathrm{ml}^{-1}$. Fase kematian bakteri terjadi pada jam ke 18 sementara fase stasioner dialami bakteri SKT-b pada selang jam ke 16-18 (Gambar 3). Bakteri yang ditumbuhkan di media pada umumnya akan mengalami empat fase pertumbuhan yaitu fase lamban, eksponensial, stasioner dan fase kematian, akan tetapi biakan dengan inokulan yang berasal dari biakan bakteri segar umumnya tidak mengalami fase lamban, sehingga fase eksponensial dapat terjadi mulai jam ke 0 .

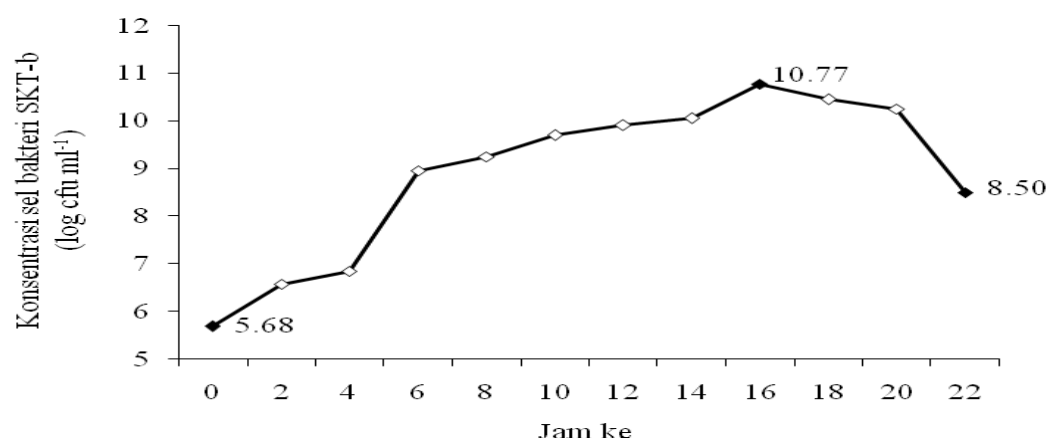

Gambar 3 Kurva pertumbuhan bakteri SKT-b yang dikultur di media SWC cair dan dihitung dengan metode total plate count

Oligosakarida yang berasal dari ubi jalar dapat dimanfaatkan sebagai sumber makanan oleh bakteri probiotik SKT-b untuk menunjang pertumbuhan bakteri tersebut secara in vitro. Penambahan oligosakarida ke media kultur meningkatkan pertumbuhan bakteri SKT-b, yang berkorelasi positif terhadap peningkatan dosis prebiotik tersebut, pada semua perlakuan konsentrasi bakteri. Jumlah inokulan yang ditambahkan ke media kultur juga menentukan konsentrasi akhir dari biakan bakteri yang dikultur. Pengurangan jumlah inokulan bakteri SKT-b menyebabkan penurunan konsentrasi akhir biakan pada semua perlakuan dosis prebiotik. Kombinasi prebiotik dan probiotik yang optimal didapatkan pada penambahan prebiotik $3 \%$ dan inokulan bakteri SKT-b konsentrasi $10^{10} \mathrm{cfu} \mathrm{ml}^{-1}$ (Gambar 4). Li et al. (2009) menyebutkan bahwa ada hubungan yang erat antara efek dosis probiotik dan prebiotik terhadap efisiensinya. Akan tetapi pemberian oligosakarida dalam jumlah tertentu dapat bersifat sebagai antinutrisi.Penelitian yang dilakukan Francis et al. (2001) menunjukkan pemberian karbohidrat yang berasal dari bungkil kedelai (kandungan total karbohidrat terlarut $12-15 \%$ ), dengan kandungan oligosakarida utama yaitu sukrosa (6-7\%), rafinosa (1-2\%) dan stakiosa (5-6\%), menurunkan konsumsi pakan pada hybrid striped bass dan rainbow trout, serta menurunkan kecernaan pakan pada trout. Ditinjau dari sisi ekonomi dosis prebiotik yang diaplikasikan dalam kegiatan budidaya berkolerasi positif dengan biaya produksi, karenanya penting untuk dievaluasi efek dosis prebiotik tersebut secara in vivo.

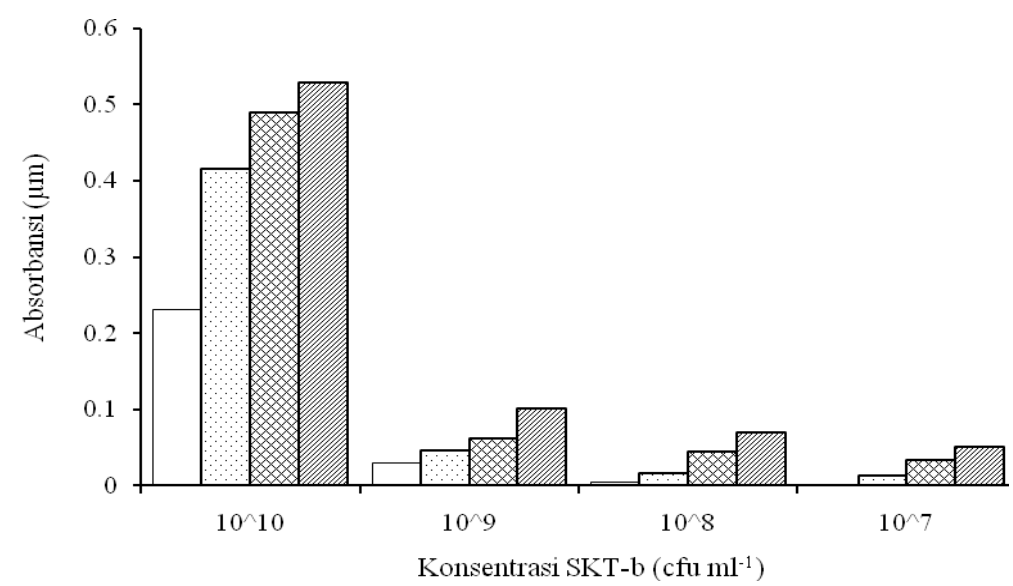

Gambar 4Nilai absorbansi biakan perlakuan kombinasi bakteri SKT-bkonsentrasi $10^{7}, 10^{8}, 10^{9}$ dan $10^{10} \mathrm{cfu} \mathrm{ml}^{-1}$ dengan prebiotik dosis $0 \%$ (kontrol) ( ), $\square$ ( ), $\square($ ) d $\square 3 \%($ ) $\square$ 


\section{SIMPULAN}

Metode pengolahan mempengaruhi komposisi kimia ubi jalar(Ipomoea batatas) berumbi putih.Pengukusan meningkatkan konsentrasi oligosakarida dimana tepung ubi kukus (metode 3) memiliki kandungan oligosakarida paling tinggi.Berdasarkan hasil uji in vitro, oligosakarida hasil ekstraksi ubi jalar mampu berperan sebagai prebiotik yang menunjang pertumbuhan bakteri probiotik SKT-b.Kombinasi prebiotik dan probiotik yang optimal didapatkan pada dosis prebiotik $3 \%$ dan probiotik SKT-b $10^{10} \mathrm{cfu} \mathrm{ml}^{-1}$ yang menunjukkan pertumbuhan bakteri probiotik paling tinggi.

\section{DAFTAR PUSTAKA}

Francis G, Harinder P, Makkar S, Becker K. 2001. Antinutritional factors present in plant-derived alternate fish feed ingredients and their effects in fish. Aquaculture 199: 197-227.

Gibson GR, Probert HM, Van Loo J. 2004. Dietary modulation of the human colonic microbiota: updating the concept of prebiotics. Nut Research Rev17: 259-275.

Gibson GR, Roberfroid M. 1995. Dietary modulation of the human colonic microbiota: introducing the concept of prebiotics. JNut125: 1401-1412.

Haryati T, Supriyati. 2010. Pemanfaatan senyawa oligosakarida dari bungkil kedelai dan ubi jalar pada ransum ayam pedaging. JITV 15 (4): 253-260.

Li J, Beiping T, Kangsen M. 2009. Dietary probiotic Bacillus OJ and isomaltooligosaccharides influence the intestine microbial populations, immune responses and resistance to white spot syndrome virus in shrimp (Litopenaeus vannamei). Aquaculture 291: 35-40.

Marlis A. 2008. Isolasi oligosakarida ubi jalar (Ipomoea batatas L) dan pengaruh pengolahan terhadap potensi prebiotiknya [tesis]. Bogor: Sekolah Pascasarjana, Institut Pertanian Bogor.

Merrifield DL, Dimitroglou A, Foey A, Davies SJ, Baker RTM, Bogwald J, Castex M, Ringo E. 2010. The current status and future focus of probiotic applications for salmonids. Aquaculture 302: 1-18.

Nayak SK. 2010. Probiotics and immunity: a fish perspective. Fish Shellfish Immunol 29: 2-14.

Putra AN. 2010. Kajian probiotik, prebiotik dan sinbiotik untuk meningkatkan kinerja pertumbuhan ikan nila (Oreochromis niloticus) [tesis]. Bogor: Sekolah Pascasarjana, Institut Pertanian Bogor.

Ringo E, Olsen RE, Gifstad TO, Dalmo RA, Amlund H, Hemre GI, Bakke AM. 2010. Prebiotics in aquaculture: a review. Aquac Nut 16: 117-136.

Rodriguez-Estrada U, Satoh S, Haga Y, Fushimi H, Sweetman J. 2009. Effect of single and combined supplementation of Enterococcus faecalis, mannan oligosaccharide and polyhydrobutyric acid on growth performance and immune response of rainbow trout Oncorhynchus mykiss.Aquac sci 57: 609617.

Syahailatua DY. 2009. Seleksi bakteri probiotik sebagai stimulator sistem imun pada udang vaname Litopenaeus vannamei [tesis]. Bogor: Sekolah Pascasarjana, Institut Pertanian Bogor.

Widanarni, Sukenda, Setiawati M. 2008. Bakteri probiotik dalam budidaya udang: seleksi, mekanisme aksi, karakterisasi dan aplikasinya sebagai agen biokontrol. J IImu Pertan Indones 13 (2): 80-89.

Widanarni, Suwanto A, Sukenda, Lay BW. 2003. Potency of Vibrio isolates for biocontrol of vibriosis in tiger shrimp (Penaeus monodon) larvae. Biotropia 20: 11-23.

Zhang Q, Ma H, Mai K, Zhang W, Liufu Z, Xu W. 2010. Interaction of dietary Bacillus subtilis and fructooligosaccharide on growth performance, non-specific immunity of sea cucumber, Apostichopus japonicas. Fish Shellfish Immunol 29: 204-211. 